\title{
ANALISIS KONTRASTIF PENGEMASAN INFORMASI DALAM BAHASA INDONESIA DAN BAHASA INGGRIS
}

\author{
Ikmi Nur Oktavianti \\ Universitas Ahmad Dablan \\ ikmi.oktavianti@pbi.uad.ac.id
}

\begin{abstract}
Abstrak
Penutur bahasa mempunyai hakikat kreatif dan inovatif. Maka dalam pemroduksian bahasa, penutur dapat memodifikasi konstruksi lingual sedemikian rupa demi kepentingan penyampaian informasi atau pesan kepada lawan tutur. Karena bahasa-bahasa di dunia mempunyai karakteristiknya masing-masing, maka fenomena pengemasan informasi menarik untuk diamati. Oleh sebab itu, makalah ini mengulas perihal pengemasan informasi dalam bahasa Indonesia dan bahasa Inggris. Di samping itu, tulisan ini berusaha memerikan faktor-faktor internal bahasa penyebab persamaan dan perbedaan pengemasan informasi di antara kedua bahasa tersebut.
\end{abstract}

Kata kunci: pemilihan sintaksis, pengemasan informasi, konstruksi nonkanonik, bahasa Indonesia, bahasa Inggris

\begin{abstract}
The nature of language user is creative and innovative. The production of language thus might allow the speaker of the language to modify the construction in order to deliver the information to the interlocutor. Due to the language-specific characteristics in each language in the world, it is then interesting to study this phenomena. Therefore, this work aims at describing information packaging in Indonesian and English. Moreover, it attempts to explain the internal factors triggering the similarities and differences of information packaging in those two languages.
\end{abstract}

Keywords: syntactic choice, information packaging, non-canonical construction, Indonesian, English 


\section{A. PENDAHULUAN}

Hal menarik yang tidak boleh dilupakan adalah adanya hakikat penutur bahasa sebagai pemakai bahasa yang bebas, kreatif, dan inovatif. Dengan demikian, penutur bahasa mempunyai cara yang beragam untuk menyampaikan informasi atau pesan yang sama. Di samping konstruksi-konstruksi kanonik, penutur bahasa juga dimungkinkan untuk menghasilkan konstruksi lingual yang nonkanonik, seperti topikalisasi, dislokasi kiri, kalimat cleft, dan beberapa yang lainnya (Creswell, 2004:1). Hal ini disebabkan oleh adanya kebebasan penutur bahasa dalam "memilih" konstruksi lingual sesuai dengan kebutuhan penyampaian pesan.

Bahasa Indonesia sebagai bahasa dengan urutan kata pada dasarnya mempunyai konstruksi kanonik SVO. Namun, dalam kebutuhannya menyampaikan pesan ke lawan tutur, penutur bahasa Indonesia "memodifikasi" konstruksi lingual sedemikian rupa sehingga lahirlah konstruksi-konstruksi nonkanonik. Perhatikan contoh-contoh berikut.

(1) Anak itu, ayahnya seorang jenderal.

(2) Dia kucinta.

(3) Sakit hati ini kuterima.

Kalimat (1), (2), dan (3) di atas merupakan hasil modifikasi sintaksis dalam upaya pengemasan informasi. Ketiganya berasal dari konstruksi kanonik bahasa Indonesia yang berpola SVO seperti di bawah ini.

(1a) Ayah anak itu seorang jenderal.

(2a) Aku mencintainya.

(3a) Aku menerima sakit hati ini.

Tidak jauh berbeda dengan bahasa Indonesia, bahasa Inggris juga mempunyai konstruksi nonkanonik untuk mengemas informasi yang ingin disampaikan penuturnya. Namun, bahasa Inggris tidak mempunyai konstruksi nonkanonik seperti pada (1), (2), dan (3) di atas. Pengedepanan konstituen dalam bahasa Inggris dapat dilakukan seperti pada contoh berikut.

(4) The steak, Ed grilled.

(Creswell, 2004:1)

(4a) Ed grilled the steak.

Kalimat (1-4) merupakan contoh pengemasan informasi. Istilah pengemasan informasi merupakan padanan dari istilah information packaging yang sudah banyak digunakan oleh peneliti bahasa (Casielles-Suarez, 2004; Schwabe dan Wrinkler, 2007; Foley via Shopen, 2007; Zimmerman dan Féry, 2010).

Di era globalisasi, peranan dan posisi bahasa Inggris semakin kuat, termasuk di Indonesia. Maka kontak antarbahasa (bahasa Indonesia dan bahasa Inggris) tidak dapat dihindari, baik dalam ranah kehidupan sehari-hari, dunia akademis, hingga kebutuhan penerjemahan. Sayangnya, banyak yang tidak menyadari bahwa kedua bahasa tersebut, terlepas dari berbagai hal yang sama, adalah dua bahasa dengan karakteristik masingmasing; salah satunya dalam pengemasan informasi. Maka banyak dihasilkan konstruksikonstruksi berbahasa Inggris dengan struktur bahasa Indonesia. Oleh sebab itu, kajian kontrastif mengenai pengemasan informasi dalam bahasa Indonesia dan bahasa Inggris penting untuk dilakukan. Terkait hal tersebut, dalam penelitian sederhana ini membahas 


\section{Analisis Kontrastif Pengemasan Informasi}

tentang 1) persamaan pengemasan informasi dalam bahasa Inggris dan bahasa Indonesia, 2) perbedaan pengemasan dalam kedua bahasa itu, 3) penyebab terjadinya persamaan dan perbedaan tersebut.

\section{B. METODE}

Pendekatan yang digunakan dalam penelitian ini adalah pendekatan kualitatif. Guba dan Lincoln (dalam Alwasiyah, 2003: 104) menguraikan beberapa karakter pendekatan kualitatif, antara lain 1) latar alamiah, 2) manusia sebagai instrumen, dan 3) sampel purposif.

Data alamiah yang digunakan dalam penelitian ini diambil secara purposif. Pengambilan sampel purposif dilakukan melalui pemilihan sumber data berdasarkan kriteria tertentu dan pertimbangan terhadap objek penelitian (Sutopo, 2006:64). Karena penelitian ini mengenai pementingan informasi dalam bahasa Indonesia dan bahasa Inggris Inggris, beberapa kriteria yang menjadi pertimbangan dalam pemilihan sumber data adalah sumber data tersebut harus berbahasa Indonesia dan bahasa Inggris dan dituliskan atau diucapkan oleh penutur asli bahasa Indonesia dan bahasa Inggris. Untuk data bahasa Inggris, penelitian ini mengambil data secara purposif dari berbagai sumber, antara lain buku tata bahasa, buku atau artikel linguistik, situs internet, kamus Oxford Advanced Learner's Dictionary (disingkat OALD) dan cerita fiksi The Twits karya Roald Dahl. Untuk data bahasa Indonesia, peneliti juga menggunakan metode reflektif dengan menggali data kebahasaan pada diri peneliti karena peneliti merupakan penutur bahasa Indonesia.

Adapun analisis dalam penelitian ini menggunakan pendekatan kontrastif. Analisis kontrastif berhubungan dengan perbandingan dua bahasa atau lebih untuk mencari perbedaan dan persamaannya yang bertujuan untuk membantu pengajaran bahasa (Fisiak dan Mickiewicz, 1981). Sementara itu, penyajian hasil analisis ditulis dengan pembahasan tentang kemiripan pengemasan informasi yang terdapat pada kedua bahasa ini terlebih dulu, lalu dilanjutkan dengan perbedaan di antara keduanya. Mengenai penyebab kemiripan dan perbedaannya, diterangkan dalam bagian tersendiri sebelum diakhiri dengan simpulan dan saran.

\section{PERSAMAAN PENGEMASAN INFORMASI DALAM BAHASA INDONESIA DAN BAHASA INGGRIS}

Bahasa Indonesia dan bahasa Inggris harus mampu mengakomodasi kebutuhan penuturnya dalam menyampaikan informasi. Oleh sebab itu, kedua bahasa tersebut mempunyai pengemasan informasi bergantung pada pemilihan sintaksis penutur. Menariknya, sebagai bahasa yang berasal dari dua rumpun yang berbeda, bahasa Indonesia dan bahasa Inggris mempunyai beberapa persamaan terkait cara mengemas informasi secara sintaksis.

\section{PENGEDEPANAN KONSTITUEN}

Salah satu ciri bahwa suatu informasi penting adalah informasi tersebut berada di bagian awal penyampaian pesan. Oleh sebab itu, ketika dalam konstruksi lingual, informasi yang penting diletakkan di depan atau dikedepankan (Tallerman, 2011:20). Pengemasan informasi semacam ini dinamakan topikalisasi. Topikalisasi menyajikan topik dari konstruksi di posisi kiri klausa atau kalimat (Foley dalam Shopen, 2007:443). 
Dalam bahasa Indonesia, dapat dijumpai pengemasan informasi melalui topikalisasi. Perhatikan contoh berikut.

(5) Buku itu kubeli.

(5a) Aku membeli buku itu.

Kalimat (5) di atas berasal dari konstruksi kanonik (5a) dengan adanya pengedepanan objek terhadap FN buku itu. Menariknya, terjadi perubahan pada morfologi verba. Afiks meN- pada verba membeli dan mencintai mengalami pelesapan..

Adapun bahasa Inggris juga mempunyai pengemasan informasi dengan cara mengedepankan konstituennya.

(6) Macadamia Nuts, I can't afford.

(7) Q: How's your son?

(Dryer, 2005)

A: Don't ask! A sportcar he wants!

(Prince, 1981:260)

Konstituen objek Macadamia Nuts dan A sportcar berada di posisi inisial klausa setelah mengelami pengedepanan dari posisinya semula dalam kalimat kanonik di bawah ini.

(6a) I can't afford Macadamia Nuts.

(7a) He wants a sportcar.

\section{PEMINDAHAN KONSTITUEN KE POSISI AKHIR}

Asumsi bahwa segala sesuatu yang diletakkan di depan adalah yang penting ternyata tidak sepenuhnya benar. Pengemasan informasi dalam kalimat tidak hanya dilakukan dengan pengedepanan konstituen, tetapi dengan meletakkan konstituen tersebut di akhir klausa atau kalimat. Berikut ini adalah contohnya dalam bahasa Indonesia.

(8) Pergi ke Yogyakarta saya.

Konstruksi di atas disebut sebagai susunan sungsang (Poedjosoedarmo, 1992:63). Susunan sungsang adalah konstruksi yang predikatnya mendahului subjek. Konstruksi semacam ini lazim dijumpai dalam kegiatan berbahasa sehari-hari. konteks informal, untuk mengemas informasi tertentu dalam konstruksi lingual yang dihasilkan penutur bahasa. FN subjek saya yang semula berada di awal kalimat, dipindahkan posisinya ke akhir kalimat. Hal ini dimungkinkan karena informasi yang dipentingkan adalah verba pergi (ke Yogyakarta)..

Serupa dengan bahasa Indonesia, bahasa Inggris juga mempunyai pemindahan posisi subjek ke akhir klausa atau kalimat.

(9) Away went the car like a whirwind.

(Quirk et al, 1972:948)

Kalimat di atas berasal dari konstruksi asali ini.

(9a) The car went away like a whirlwind.

FN subjek the car mengalami pemindahan posisi dari posisinya yang mendahului 


\section{Analisis Kontrastif Pengemasan Informasi}

verba went away ke posisi paling akhir sesudah verba tersebut. Hal ini diasumsikan karena si penutur ingin mementingkan informasi yang terkandung pada verba atau justru ingin menekankan si subjek (the car).

Selain konstruksi yang dihasilkan dari operasi postposing berupa inversi subjek ke posisi akhir kalimat, bahasa Indonesia juga mempunyai konstruksi lain yang melibatkan pemindahan konstituen ke akhir kalimat, yaitu ekstraposisi. Ekstraposisi dalam bahasa Indonesia tidak meninggalkan jejak untuk posisi yang ditinggalkan oleh konstituennya (Lapoliwa, 1990:349-350). Perhatikan beberapa contoh di bawah ini.

(10) Bahwa dia tidak bersalah sudah jelas.

(10a) Sudah jelas bahwa dia tidak bersalah.

Klausa nomina bahwa dia bersalah dapat diekstraposisikan ke bagian akhir dan diperolehnya kalimat (10a) yang merupakan konstruksi nonkanonik sebagai bagian pengemasan informasi yang dilakukan oleh penutur bahasa.

Adapun ekstraposisi mempunyai batasan, yakni klausa dengan FN hulu harus diekstraposisikan bersama dengan FN hulunya (Lapoliwa, 1990:349).

(11) Pendapat bahwa dia bersalah ternyata keliru.

(11a) Ternyata keliru pendapat bahwa dia bersalah.

(11b) *Pendapat ternyata keliru bahwa dia bersalah.

Kalimat (11b) tidak gramatikal karena terdapat FN hulu pendapat yang harus diekstraposisikan bersama-sama dengan bahwa dia bersalah sebagai satu kesatuan.

Pengemasan informasi tentu tidak dapat dilepaskan dari motivasi penuturnya. Demikian halnya dengan pengemasan informasi melalui ekstraposisi. Menurut Lapoliwa (1990:347), ekstraposisi berfungsi untuk memudahkan pendengar dalam menangkap informasi yang dimaksudkan, maka informasi diletakkan di akhir kalimat agar fokus lawan tutur dapat didapat.

Adapun bahasa Inggris juga mempunyai konstruksi ekstraposisi yang dihasilkan dari peletakkan konstituen di posisi akhir klausa atau postposing (Caro, 1993:118). Amati contoh-contoh berikut.

(12) Something came up that caused concern.

(13) Some guy was there with red hair.

(14) The girl arrived in blue dress.

(Caro, 1993)

Ketiga kalimat di atas merupakan konstruksi ekstraposisi yang melibatkan pemisahan salah satu bagian dari FN subjek. Bandingkan dengan konstruksi kanoniknya di bawah ini.

(12a) Something that caused concern came up.

(13a) Some guy with red hair was there.

(14a) The girl in blue dress arrived.

FPrep with red hair, in blue dress dan FV that caused concern pada ketiga kalimat tersebut merupakan bagian dari FN subjek some guy, the girl, dan something yang dipisahkan karena frasa-frasa tersebut dipindahkan ke posisi akhir. 


\section{PENGEMASAN INFORMASI MELALUI DISLOKASI KIRI}

Bahasa Indonesia mempunyai konstruksi nonkanonik dislokasi kiri sebagai salah satu alternatif pengemasan informasi dalam berbahasa (Lapoliwa, 1990; Oktavianti, 2011). Dalam dislokasi kiri terdapat konstituen yang dipindahkan ke bagian paling kiri kalimat dan meninggalkan jejak di posisi semula. Perhatikan contoh berikut ini.

(15) Buku itu, aku membelinya.

(15a) Aku membeli buku itu.

FN buku itu yang semula berada di posisi akhir (15) dikedepankan ke awal kalimat. Pemindahan tersebut diiringi dengan ditinggalkannya jejak berupa santiran pronomina nya yang merujuk pada entitas buku itu.

Selain objek, dalam bahasa Indonesia subjek juga dapat didislokasikirikan. Berikut contohnya.

(16) Susi, dia sakit kemarin.

FN Susi yang semula adalah subjek dan sudah berada di posisi awal kalimat dapat lebih ditonjolkan lagi dan di posisinya semula ditinggalkan jejak berupa pronomina dia. Menurut Oktavianti (2011:157), FN Susi yang sudah dikedepankan tersebut menjadi anteseden bagi pronomina dia dan sesungguhnya berada di luar klausa $\left(K^{\prime}\right)$.

Bukan hanya objek dan subjek, dislokasi kiri juga dapat dilakukan pada konstituen yang menempati fungsi keterangan.

(17) Bom itu diletakkan di jembatan api.

(17a) Di jembatan api, bom itu diletakkan di sana.

FPrep di jembatan api dipindahkan ke awal kalimat dari posisinya semula di bagian akhir kalimat. Pemindahan tersebut menekankan bahwa frase preposisi di jembatan api merupakan informasi yang dipentingkan oleh penutur.

(18) The kitten, what's it up to now?

(Caro, 1993)

(4) The steak, Ed grilled it.

Konstituen The kitten dan The steak yang didislokasikan pada mulanya adalah objek pada konstruksi ini.

(18a) What's the kitten up to now?

(4a) Ed grilled the steak.

FN John dan the steak dikedepankan ke awal kalimat dan di posisinya semula (objek kalimat) ditinggalkan jejak pronomina. Artinya, John dan the steak merupakan anteseden bagi him dan it. Pemindahan posisi terjadi agar informasi John dan The steak mendapat penekanan karena merupakan informasi penting yang disampaikan.

\section{PENGEMASAN INFORMASI DENGAN CLEFT}

Pengemasan informasi tidak sekadar berkaitan dengan pemindahan konstituen, tetapi juga bisa dilakukan dengan pembelahan. Yang dimaksud dengan pembelahan adalah 
"membelah" suatu konstruksi menjadi dua bagian dengan klausa relatif (Crystal, 2008:79). Konstruksi nonkanonik yang dihasilkan dengan pembelahan dapat dibedakan menjadi dua macam, yaitu it-cleft dan pseudo-cleft.

Bahasa Indonesia mempunyai operasi sintaksis clefting atau pembelahan untuk menghasilkan konstruksi nonkanonik dalam mengemas informasi. Menurut Butar-Butar (1978), yang dimaksud dengan kalimat cleft dalam bahasa Indonesia adalah contoh berikut.

(19) Pak Suroso yang datang tadi malam.

Kalimat tersebut berasal dari konstruksi asali di bawah ini.

(19a) Pak Suroso datang tadi malam.

Perbedaan antara kalimat (19) dan (19a) adalah terdapat presuposisi pada kalimat (19) tentang siapa yang datang tadi malam.

Terkait konstruksi cleft, bahasa Inggris mempunyai konstruksi cleft yang juga beragam. Konstruksi it-cleft mempunyai subjek semu it yang secara semantis kosong. Konstruksi itcleft mengekspresikan hubungan identitas antara elemen yang dipentingkan dan klausa relatifnya (Collins, 2002:2). Perhatikan contohnya di bawah ini.

(20) It's you that's getting shorter!

(Roald Dahl, 2007:21)

Pada kalimat di atas, subjek semu it menjadi pengisi subjek sintaksis dan terjadi pembelahan karena pada dasarnya konstruksinya adalah di bawah ini.

(20a) You are getting shorter.

Konstruksi di atas mengalami pembelahan menjadi dua: (a) it is you dan (b) you are getting shorter yang digabungkan menjadi kalimat (20) tersebut. Pada konstruksi di atas terdapat klausa relatif (adjective clause) that is getting shorter yang menjelaskan FN you. Terjadinya pembelahan itu tidak dapat dilepaskan dari upaya pengemasan informasi seorang penutur dalam penyampaian pesannya. Perhatikan contoh lainnya berikut ini.

(21) It is Mary who is the dancer.

(Cann, 2007:13)

Kalimat di atas juga mengalami pembelahan. Konstruksi asalinya adalah

(21a) Mary is the dancer.

Kalimat asali itu dikemas sedemikian rupa dengan menambahkan "it is" sehingga seolah-olah terjadi pembelahan (a) it is Mary dan (b) who is the dancer.

Selain it-cleft, konstruksi belah juga dapat berupa pseudo-cleft. Adapun yang dimaksud dengan istilah pseudo-cleft adalah kalimat yang seolah-olah seperti it-cleft tetapi sejatinya berbeda. Yang membedakan adalah pemakaian kata tanya wh yang membentuk klausa nomina (noun clause) di awal kalimat. Amati contoh ini.

(22) What I want is a good review.

(Cann, 2007:14)

Konstruksi di atas berasal dari kalimat kanonik berikut.

(22a) I want a good review.

32 | Ranah, Volume 3, Nomor 1, Juli 2014 
Secara sepintas kalimat di atas tampak serupa dengan it-cleft karena terdapat dua bagian: (a) what I want dan (b) a good review; dua bagian tersebut seolah-olah terbelah. Dalam konstruksi pseudo-cleft, tidak terdapat presuposisi.

Dalam bahasa Indonesia juga dijumpai konstruksi cleft yang tidak diawali oleh presuposisi. Pada konstruksi semacam ini digunakan perangkai yang seperti pada contoh di bawah ini.

(23) Yang saya baca (adalah) surat kabar kemarin.

(Butar-Butar, 1978:14)

Kalimat di atas berasal dari kalimat asali berikut ini.

(23a) Saya membaca surat kabar kemarin.

Kalimat (23a) tersebut seolah mengalami pembelahan dengan penambahan perangkai yang di awal kalimat untuk membentuk klausa nomina dan penggunaan "kata pemisah" adalah.

\section{PEMBALIKAN LOKATIF}

Pengemasan informasi ternyata sangat beragam. Yang lazim adalah pemindahan konstituen, tidak terkecuali pemindahan akibat pembalikan lokatif. Istilah pembalikan lokatif dapat dijumpai dalam Levin dan Hovav (2005:195) yang merujuk pada pemindahan konstituen yang menunjukkan lokasi yang terletak setelah verba ke posisi sebelum verba. Amati kalimat berikut.

(24)Burung perkutut bertengger di dalam sangkar.

Jika diamati kalimat di atas, burung perkutut sebagai subjek merupakan entitas yang sedang dideskripsikan lokasinya oleh frase preposisi di dalam sangkar. Hal ini ditandai dengan adanya verba bertengger yang bersifat lokatif. Apabila penutur berusaha mementingkan lokasi, kemungkinan besar konstruksi di atas akan ditransformasikan menjadi kalimat di bawah ini.

(24a) Di dalam sangkar bertengger burung perkutut.

Dalam bahasa Inggris, pengemasan informasi yang dipentingkan dapat pula direalisasikan dalam pembalikan lokatif. Perhatikan contoh berikut.

(25) Under the bridge stood a dilapidated shack.

(Caro, 1993)

Kalimat di atas mengalami pembalikan posisi dari konstituen yang berada sebelum verba (a dilapidated shack) dan konstituen yang berada setelah verba (under the bridge). Konstituen yang berada sebelum verba adalah entitas yang sedang dibicarakan; adapun konstituen yang berada setelah verba bersifat lokatif. Dengan dibaliknya posisi keduanya, maka lokasi entitas tersebut berada di posisi sebelum verba dan entitasnya berubah posisi setelah verba. Hal ini karena penutur tampaknya ingin mementingkan informasi lokasi dari entitas tersebut. Berikut ini adalah kalimat asali dari kalimat (25).

(25a) A dilapidated shack stood under the bridge. 
Bahasa Inggris memungkinkan terjadinya pembalikan semacam ini ketika verba dalam konstruksi tersebut bersifat lokatif. Verba stood pada contoh di atas bersifat lokatif. Demikian halnya dengan verba sit pada contoh berikutnya.

(26)At the top of that mountain sits an eagle's nest.

(Farrell, 2005:98)

Konstituen at the top of that mountain sebenarnya berada di posisi setelah verba sit. Akan tetapi, karena adanya pembalikan lokatif, maka terjadi perubahan posisi; benda yang sedang dijelaskan lokasinya an eagle's nest justru berpindah ke akhir kalimat.

\section{PEMASIFAN}

Pemindahan konstituen ternyata dapat pula disebabkan oleh perubahan diatesis verba; termasuk perubahan sudut pandang dalam melihat tindakan yang disebutkan oleh verba. Pembahasan tentang hal ini tidak dapat dilepaskan dari konstruksi pasif. Konstruksi pasif adalah konstruksi dengan subjek gramatika yang berperan sebagai penderita dari suatu tindakan (Crystal, 2008:153). Perhatikan contoh ini.

(27) Ali membaca buku itu.

Kalimat di atas merupakan kalimat aktif yang terdiri atas FN Ali sebagai subjek dan buku itu sebagai objek; kalimat tersebut mempunyai verba membaca sebagai predikatnya. Ketika diatesis verba yang semula aktif (membaca) diubah menjadi pasif (dibaca), sudut pandangnya diubah dari pelaku menjadi penderita, maka didapati kalimat seperti di bawah ini.

(27a) Buku itu dibaca (oleh) Ali.

Pada kalimat (27a) tersebut, FN objek buku itu menjadi subjek gramatika (bukan subjek logika) dan berperan semantis sebagai penderita dari tindakan yang dinyatakan oleh verba. Adapun pemakaian oleh sesungguhnya bersifat opsional. Ketika dilesapkan pun, konstruksi yang dihasilkan masih gramatikal.

Bahasa Inggris, seperti bahasa-bahasa lain di dunia, juga mempunyai konstruksi yang berhubungan dengan perspektif keagenan, yakni pasif. Berikut adalah contohnya.

(28) The letter was written by a doctor.

(28a) A doctor write a letter.

(Crystal, 2008:353)

Verba write pada kalimat (28a) berdiatesis aktif dan mengalami perubahan diatesis menjadi pasif pada kalimat (28). Dengan demikian, terjadi perubahan posisi argumen. A doctor yang semula merupakan pelaku dan a letter merupakan penderita bertukar posisi karena a letter lebih dipentingkan pada konstruksi pasifnya. Dengan kata lain, yang menempati fungsi subjek adalah argumen yang berperan semantis penderita.

Konstruksi pasif bersifat mengurangi keagenan. Ada kalanya agen dihadirkan seperti pada contoh di atas. Ada kalanya tidak. Konstruksi pasif dalam bahasa Indonesia dan bahasa Inggris mampu melesapkan agen seperti berikut.

(29) The city is industrialized now.

(Crystal, 2008:353)

(30) Sepatu baru saya dicuri. 
Konstruksi pasif di atas secara sepintas sama dengan yang dicontohkan sebelumnya. Namun, konstruksi di atas mempunyai perbedaan yang mendasar, yakni pelaku dari tindakan yang dijelaskan oleh verba tidak penting untuk disebutkan sehingga tidak dijumpai frase by + nomina dan oleh + nomina.

\section{PERBEDAAN PENGEMASAN INFORMASI ANTARA BAHASA INDONESIA DAN BAHASA INGGRIS}

Sebagai dua bahasa yang berasal dari rumpun yang berbeda, tentu bahasa Indonesia dan bahasa Inggris mempunyai perbedaan karakteristik bahasa. Hal ini tentu akan berpengaruh pada perbedaan cara pengemasan informasi dalam klausa atau kalimat. Berikut ini akan diulas perbedaan pengemasan informasi di antara kedua bahasa tersebut.

\section{PERBEDAAN DALAM TOPIKALISASI}

Kendati bahasa Indonesia dan bahasa Inggris mempunyai konstruksi topikalisasi atau pengedepanan konstituen, ternyata terdapat perbedaan yang cukup signifikan di antara keduanya. Sebagaimana telah dijelaskan sebelumnya, bahasa Indonesia mempunyai perilaku morfologi yang unik dalam pengedapan objek. Amati contoh konstruksi topikalisasi di bawah ini.

(2) Dia kucinta.

(3) Sakit hati ini kuterima.

Pada topikalisasi tersebut, pengedepanan objek menyebabkan perubahan morfologi verba. Verba yang semula berafiks $m e N$-, afiks tersebut lesap pada hasil penopikan. Apabila afiks meN- masih melekat, konstruksi yang dihasilkan justru tidak lazim dijumpai dalam bahasa Indonesia.

(2b) ? Dia aku mencinta.

(3b) ? Sakit hati ini aku menerima.

Konstruksi di atas barangkali dapat menjadi lebih lazim dengan adanya santiran pronomina sehingga lebih merupakan konstruksi dislokasi daripada topikalisasi.

(2c) Dia, aku mencintainya.

(3c) Sakit hati ini aku menerimanya.

Menariknya, bahasa Inggris tidak mempunyai keunikan morfologi verba dalam penopikan objeknya.

(31) I never good at math. But sciences I enjoy.

(32)Beas, he likes.

(Dryer, 2005)

Pada contoh topikalisasi bahasa Inggris di atas terlihat bahwa bahasa Inggris tidak mempunyai kekhasan pada morfologi verba ketika terjadi pengedepanan objek. Oleh sebab itu, kalimat (2) jika dipadankan dalam bahasa Inggris akan menjadi kalimat seperti berikut.

(2d) Him, I love. 


\section{PERBEDAAN DALAM KONSTRUKSI CLEFT}

Apabila bahasa Inggris mempunyai-setidaknya-dua tipe konstruksi cleft (it-cleft dan pseudo-cleft), bahasa Indonesia tidak seberagam itu. Konstruksi cleft dalam bahasa Indonesia dimulai dengan perangkai yang yang merelatifkan klausa. Bahasa Indonesia tidak mempunyai konstruksi yang ekuivalen dengan it-cleft dalam bahasa Inggris.

(33) It was only years later that I realised what he meant.

(Downing, 2006)

Dalam bahasa Indonesia, konstruksi di atas dapat dipadankan menjadi kalimat di bawah ini.

(34) Beberapa tahun kemudianlah saya paham apa yang ia maksud.

Sama halnya ketika menerjemahkan kalimat (19) di atas ke dalam bahasa Inggris, maka akan diperoleh kalimat (19b):

(19b) It was Mr. Suroso who came last night. dan bukan:

(19c) Mr Suroso came last night. atau:

(19d) * Mr. Suroso who came last night.

Bahasa Indonesia tidak menggunakan satuan lingual yang ekuivalen dengan subjek kosong it untuk membentuk kalimat cleft. Pemakaian partikel lah dimungkinkan untuk memberi penegasan. Contohnya sebagai berikut.

(35) It was Nick that Stan saw at the party.

(www.grammar.about.com)

(36) Nick lah yang dilihat oleh Stan di pesta.

\section{PERBEDAAN DALAM PEMASIFAN}

Menurut Chung (1989:3-7), bahasa Indonesia mempunyai dua jenis pasif. Dua jenis pasif tersebut adalah pasif kanonis (pasif dasar) dan pasif diri. Pasif kanonis adalah konstruksi pasif yang dalam bahasa Indonesia dimarkahi dengan pemakaian oleh pada bentuk yang dipasifkan, sebagaimana yang sudah dibahas sebelumnya. Adapun salah satu kekhasan bahasa Indonesia adalah terletak pada konstruksi pasif diri atau pasif pronomina. Berikut contohnya.

(37) Saya membaca buku itu.

(37a) Buku itu dibaca oleh saya.

(37b) Buku itu saya baca.

Kalimat (37) adalah contoh konstruksi aktif. Sementara itu, kalimat (37a) dan (37b) adalah contoh dari kalimat pasif kanonis dan pasif diri. Bentuk pasif diri tersebut hasil topikalisasi objek dengan pelesapan prefiks $m e N$ - secara wajib. Dalam bahasa Inggris bentuk pasif diri seperti di bawah ini tidak dimungkinkan.

(38) I read your writing.

(OALD, 2005:1254) 
(38a) ?Your writing I read.

(38b) *Your writing I have read.

Selain keunikannya karena mempunyai konstruksi pasif diri, bahasa Indonesia juga mempunyai konstruksi pasif adversatif. Pada konstruksi pasif adversatif, terjadi perubahan transitivitas verba yang semula intransitif menjadi transitif. Di samping itu, terdapat penambahan argumen sebagai penderita (Kroeger, 2005:279).

(39) Paman kena tilang polisi.

(39a) Paman ketilang polisi.

(40) Ali kejatuhan tangga.

Verba kena tilang, ketilang, dan kejatuhan dalam contoh-contoh di atas merupakan verba pasif adversatif yang mengandung unsur ketidaksengajaan. Jenis pasif semacam ini hadir dalam bahasa Indonesia diasumsikan karena adanya interferensi dari bahasa Jawa. Namun, menurut Poedjosoedarmo (1982:59), pada dasarnya afiks ke-/-an ini sudah dimiliki oleh bahasa Melayu, tetapi tidak terlalu produktif. Akibat adanya pemengaruhan bahasa Jawa terhadap bahasa Indonesia, afiks ini mengalami peningkatan pemakaian.

Sebaliknya, bahasa Inggris tidak mempunyai konstruksi pasif adversatif. Konstruksi pasif dalam bahasa Inggris cenderung seragam, dengan atau tanpa pelaku.

(41)The metropolis has been scorched by the dragon's fiery breath.

(42) When her house was invaded, Penelope had to think of ways to delay her remarriage. (www.writingcenter.unc.edu)

\section{PERBEDAAN DALAM ALTERNASI TRANSITIVITAS}

Bahasa Inggris dapat mengemas informasinya melalui alternasi transitivitas; tidak ada perubahan secara morfologis pada verba, tetapi melibatkan perubahan sudut pandang dalam melihat suatu peristiwa. Alternasi transitivitas melibatkan perubahan transitivitas dari verba yang terdapat pada suatu klausa (Levin, 1993:25). Pada kalimat di bawah ini, contohnya, verba broke mengalami alternasi transitivitas dari verba transitif pada (43) dan verba intransitif pada (43a).

(43) The boy broke the window.

(43a) The window broke.

(Levin dan Hovav, 2005:1)

Verba broke pada contoh di atas tidak mengalami perubahan morfologis, tetapi antara kalimat (43) dan (43a) berbeda karena terjadi pergeseran sudut pandang dari pelaku tindakan ke hasil dari tindakan. Alternasi semacam ini dinamakan juga dengan alternasi kausatif/inkoatif (Levin, 1993:27).

Adapun bahasa Indonesia tidak mempunyai alternasi transitivitas pada verba sebagaimana bahasa Inggris. Konstruksi kausatif dalam bahasa Indonesia dimarkahi dengan meN-, sedangkan konstruksi inkoatifnya tidak dimarkahi afiks. Dengan kata lain, terjadi perubahan morfologis pada verba.

(44) Ali memecahkan gelas.

(45) Gelasnya pecah. 
Pada contoh di atas, pada konstruksi kausatif, verba pecah dilekati oleh afiks meN-/kan, sedangkan ketika sudut pandang diubah menjadi hasil dari tindakan, maka afiks-afiks pada verba tersebut dihilangkan.

\section{E. MENGAPA TERDAPAT PERSAMAAN DAN PERBEDAAN?}

Pembahasan mengenai persamaan dan perbedaan pengemasan informasi antara bahasa Inggris dan bahasa Indonesia akan lebih komprehensif jika disertai dengan penjelasan ihwal mengapa dapat terjadi persamaan dan perbedaan. Oleh sebab itu, bagian selanjutnya akan menguraikan beberapa faktor-kendati belum mencakup semua-yang melatarbelakangi terjadinya persamaan dan perbedaan cara mengemas informasi pada kedua bahasa tersebut.

\section{PERBEDAAN KEKETATAN URUTAN KATA}

Setelah diuraikan perwujudan pengemasan informasi penting dalam bahasa Inggris dan bahasa Indonesia, dapat dilihat bahwa Bahasa Inggris dan Bahasa Indonesia mempunyai banyak persamaan. Hal ini tidak mengherankan karena kedua bahasa tersebut, walaupun berasal dari rumpun yang berbeda, mempunyai urutan kata kanonik yang sama, yaitu SVO. Beberapa verba yang bersifat transitif/intransitif dalam bahasa Inggris juga bersifat sama dalam bahasa Indonesia.

(46) Icuk makan nasi goreng.

(47) Bill pounded the metal.

(Levin, 1993:26)

Verba makan dan pound masing-masing diikuti oleh objek nasi goreng dan the metal yang merujuk pada makanan apa yang dimakan. Di samping itu, kedua verba tersebut juga didahului oleh subjek sebagai pelaku dari tindakan makan (Icuk dan Bill).

\section{PENGISI FUNGSI PREDIKAT YANG BERBEDA}

Bahasa Inggris dan bahasa Indonesia mempunyai satu persamaan mendasar, yaitu urutan kata yang berupa SVO. Walupun sama-sama SVO, sesungguhnya terdapat perbedaan yang cukup signifikan pada keduanya. Bahasa Inggris selalu berurutan SVO. Verba dalam bahasa Inggris dapat berupa dua kemungkinan, yaitu verba leksikal dan verba fungsional. Ketika konstruksinya tidak mempunyai verba leksikal, dihadirkanlah verba fungsional.

(47) Bill pounded the metal.

(48) Mary is a student.

(Cann, 2007:13)

Pada kalimat (47), terdapat verba leksikal pound sebagai pengisi fungsi predikat. Sementara itu, kalimat (48) tidak mempunyai verba leksikal. Untuk mengisi fungsi predikat, kopula be sebagai verba fungsional wajib hadir. Oleh sebab itu, konstruksi di bawah ini tidak gramatikal dalam bahasa Inggris.

(48a) *Mary a student. 
Verba, baik leksikal maupun fungsional, wajib hadir dalam bahasa Inggris karena bahasa Inggris memerlukan satuan lingual yang dapat dilekati oleh kala (tense) sebagai salah satu syarat wajib suatu konstruksi bahasa Inggris (Baker, 2005).

Tidak demikian halnya dengan bahasa Indonesia, bahasa Indonesia tidak mempunyai kala yang wajib dilekatkan pada verbanya. Oleh sebab itu, fungsi predikat dalam bahasa Indonesia tidak harus diisi oleh verba.

(49) Ayahku guru.

(49a) Ayahku (adalah) guru.

Pada kalimat (49a) di atas, pemakaian kopula adalah bersifat opsional; bisa lesap atau hadir. Hal ini karena satuan lingual yang dihubungkan adalah nomina. Meskipun demikian, pada contoh di bawah ini, kopula wajib hadir.

(50) Linguistik adalah ilmu tentang bahasa.

Namun, dalam contoh-contoh berikut ini, sebaliknya, kopula justru tidak wajib hadir.

(51) Dia cantik.

(52) Andin sakit.

(54a) * Dia (adalah) cantik.

(55a) *Andin (adalah) sakit.

Kehadiran kopula adalah pada contoh di atas justru menjadikan kalimat tidak gramatikal dalam bahasa Indonesia. Hal ini tidak dapat dilepaskan dari predikat nonverba yang ada dalam contoh-contoh tersebut berkelas kata adjektiva sehingga tidak memungkinkan untuk dihubungkan dengan adalah.

\section{BAHASA INDONESIA PENAMPIL TOPIK DAN BAHASA INGGRIS PENAMPIL SUBJEK}

Secara tipologi, bahasa Inggris merupakan bahasa penampil subjek (subject-prominent language), sebagaimana bahasa-bahasa Indo-Eropa lainnya (Li dan Thompson, 1976). Hal ini dapat dibuktikan dengan contoh sederhana berikut.

(53) I have got a stomach ache.

$$
\text { (www.usingenglish.com) }
$$

(54) She cut my finger on a piece of glass.

(OALD, 2005:378)

Kedua kalimat itu berkaitan dengan rasa sakit. Ketika berbicara tentang rasa sakit, yang ditonjolkan bukanlah bagian tubuh yang sedang merasakan sakit, melainkan si subjek.

Selain itu, bahasa Inggris sebagai bahasa subjek juga bersifat non-pro-drop atau tidak dapat melesapkan subjeknya, setidaknya secara sintaksis. Amati contohnya berikut ini.

(55) It rains.

(Moro, 1997)

Bahasa Inggris wajib menghadirkan subjek semu it untuk mengisi fungsi sintaksis subjek, walaupun secara semantis it bersifat kosong atau meaningless. Dengan kata lain, verba dalam bahasa Inggris harus selalu mempunyai valensi yang menyebabkan terealisasinya kehadiran subjek sintaksis (Pavey, 2010; Moro, 1997). 
Bahasa Indonesia memang punya unsur subjek, namun tidak selalu demikian. Bahasa ini lebih cocok disebut bahasa penampil topik (Kaswanti Purwo:1984). Amati contohnya berikut.

(56) Perutku sakit.

(57) Jariku terluka.

Pada kedua contoh di atas, untuk menyatakan rasa sakit bahasa Indonesia memfokuskan pada bagian tubuh yang sedang merasakan rasa sakit dan bukan si subjek.

Sebagai bahasa penampil topik, bahasa Indonesia tidak mewajibkan hadirnya subjek sintaksis dalam konstruksinya. Hal ini dapat diamati dalam konstruksi berverba meteorologis.

(58) Hujan!

(59) Panas!

Unsur subjek wajib hadir pada bahasa Inggris, namun hal ini tidak berlaku dalam bahasa Indonesia. Dalam bahasa Indonesia, kalimat dengan verba bervalensi kosong (zero) pun telah lazim ada (Wijana, 2010) sehingga menyatakan cuaca dalam bahasa Indonesia tidak perlu kehadiran argumen eksternal untuk mengiringi verba cuaca. Dengan kata lain, verba meteorologis atau verba cuaca dalam bahasa Indonesia bervalensi nol. Hal ini dapat menjadi salah satu bukti bahwa bahasa Indonesia dapat dikategorikan sebagai bahasa penampil topik daripada bahasa penampil subjek.

Sebagai pandangan lain, konstruksi demikian dinamakan klausa eventif yang tidak terbatas pada cuaca (Soeparno, 2008:74). Pendapat ini dikemukakan oleh pengikut aliran tagmemik yang menyatakan bahwa klausa semacam ini terdiri atas subjek sebagai item (peran kosong) yang bersifat opsional dan predikat wajib hadir diisi oleh verba yang bersifat eventif (cuaca, bencana alam, dan sejenisnya).

(60) Gempa!

(61) Tsunami!

Kedua contoh di atas merupakan konstruksi yang tidak berkaitan dengan kondisi cuaca, tetapi bencana alam. erba dengan argumen kosong dapat pula disebut sebagai verba dalam konstruksi eventif.

\section{F. SIMPULAN DAN SARAN}

Berdasarkan pembahasan di atas dapat diamati bahwa bahasa Indonesia dan bahasa Inggris mempunyai cara mengemas informasi masing-masing. Di antara pengemasan tersebut ada beberapa persamaan. Terlepas dari persamaan di antara keduanya, terdapat pula perbedaan pengemasan informasi. Secara ringkas, persamaan dan perbedaan tersebut dirangkum dalam tabel di berikut ini. 


\begin{tabular}{|c|c|c|}
\hline Kenstralk: & $\begin{array}{l}\text { Contoh din bolms } \\
\text { Indracsin }\end{array}$ & 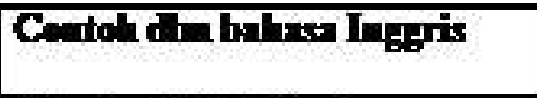 \\
\hline Tonlankisgsi & Dia hackith & The stant Ed grillod \\
\hline $\begin{array}{l}\text { Sosuman } \\
\text { simpsong }\end{array}$ & 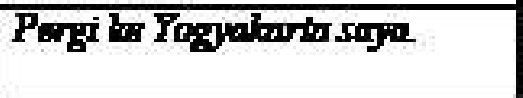 & $\begin{array}{l}\text { Anay want the con lits a } \\
\text { whirhtwi. }\end{array}$ \\
\hline Flestrapasisi & 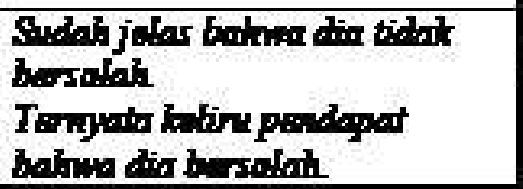 & $\begin{array}{l}\text { Soin guy was fher with red } \\
\text { hair. } \\
\text { The girl arrived in bhus doss. }\end{array}$ \\
\hline $\begin{array}{l}\text { Dislch pasi } \\
\text { Kini }\end{array}$ & 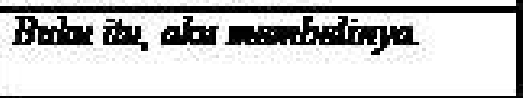 & The stank Ed gillied it. \\
\hline $\begin{array}{l}\text { Dislorati } \\
\text { Kman }\end{array}$ & - & 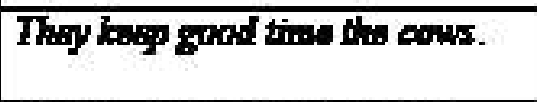 \\
\hline \multirow[t]{3}{*}{ Cat } & - & If is Mory who is the dinxer. \\
\hline & Pal Swroso youg damig & - \\
\hline & Yavg sagi bare stond forbar & What I wand is a gaod rivinw. \\
\hline $\begin{array}{l}\text { Penbalitam } \\
\text { lol+atif }\end{array}$ & 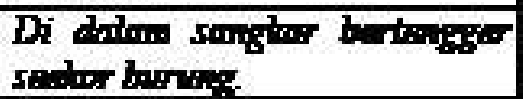 & 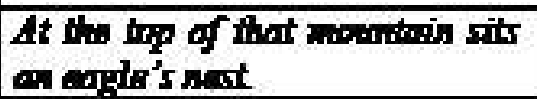 \\
\hline Pitif & 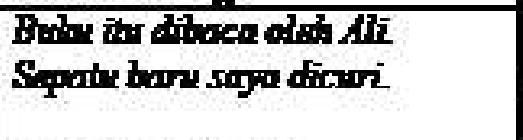 & 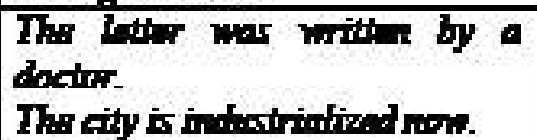 \\
\hline & 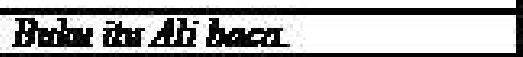 & - \\
\hline & 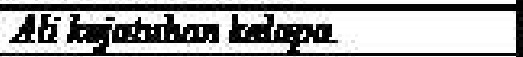 & - \\
\hline $\begin{array}{l}\text { Altirnati } \\
\text { transitivitas }\end{array}$ & - & $\begin{array}{l}\text { The boy bolos the window. } \\
\text { The windon borte. }\end{array}$ \\
\hline
\end{tabular}

Penelitian ini tentu saja masih jauh dari sempurna. Banyak aspek yang belum dijelaskan dalam pembahasan mengenai pengemasan informasi dalam bahasa Indonesia dan bahasa Inggris. Selain itu, penelitian berbasis korpus juga perlu dilakukan agar mendapat gambaran pemakaian bahasa yang lebih empiris. 


\section{Daftar Pustaka}

Alwasiyah, A Chaedar. 2009. Pokok-Pokoknya Kualitatif: Dasar-Dasar Merancang dan Melakukan Penelitian Kualitatif. Jakarta: PT Dunia Pustaka

Baker, Mark. 2005. Lexical Categories. Cambridge. Cambridge University Press.

Butar-Butar, Maruli. 1976. "Some Movement Transformations and their Constraints in Indonesian." Disertasi Ph.D di Indiana University.

1978. "Suatu Pengamatan tentang Kalimat Cleft (Cleft Sentence) dalam Bahasa Indonesia." Dalam Majalah Bahasa dan Sastra, VI(3): 11-17.

Caro, Elena Martinez. 1993. "Non-SVO Constructions in English: Some Pragmatic and Functional Considerations", dalam Revista Alicantina de Estudios Ingleses, 6(1):115-130.

Casielles-Suarez, Eugenia. 2004. The Syntax-Information Structure Interface. London: Routledge.

Chung, Sandra. 1989. "On the Subject of Two Passives in Indonesia." Dalam: Kaswanti Purwo, Bambang (ed.). 1989. Serpih-Serpih Telaah Pasif Bahasa Indonesia. Yogyakarta: Penerbit Kanisius.

Collins, Peter C. 2002. Cleft and Pseudo-Cleft Constructions in English. London: Routledge.

Creswell, Casandre. 2004. Syntactic Form and Discourse Function in Natural Language Generation. New York: Routledge.

Crystal, David. 2008. A Dictionary of Linguistics and Phonetics. Oxford: Blackwell.

Durham, Mercedes. 2011. "Right Dislocation in North England: Frequency and Use-Perception Meets Reality." Dalam English World-Wide, 32(3): 257279.

Emeis, M.G. 1952. Bunga Rampai Melaju Kuno. Jakarta: J.B. Wolters

Fisiak, J. dan Mickiewicz, A.. 1981. Contrastive Linguistics and the Language Teacher. Oxford: Pergamon Press

Kaswanti Purwo, Bambang. 1984. Deiksis dalam Bahasa Indonesia. Jakarta: Balai Pustaka

Kroeger, Paul. 2005. Analyzing Grammar: An Introduction. Cambridge: Cambridge University Press.

Lapoliwa, Hans. 1990. Klausa Pemerlengkapan dalam Bahasa Indonesia. Yogyakarta: Penerbit Kanisius.

Levin, Beth. 1993. English Verb Classes and Alternations. Chicago: The University of Chicago.

Levin, Beth dan Hovav, Malka Rapaport. 2005. Argument Realization. Cambridge: Cambridge University Press.

Li, Charles dan Thompson, Sandra A. 1976. "Subject and Topic: A New Typology of Language", dalam Li, Charles (Ed). 1976. Subject and Topic. New York: Academy Press.

Moro, Andrea. 1997. The Raising of Predicate. Cambridge: Cambridge University

Oktavianti, Ikmi Nur. 2011. "Dislokasi Kiri dalam Bahasa Indonesia”, dalam Kibas Cenderawasih, 7(2): 151-166.

Pavey, Emma L. 2010. The Structure of Language: An Introduction to Grammatical Analysis. Cambridge: Cambridge University Press.

Poedjosoedarmo, Soepomo. 1982. Javanese Influence on Indonesian (Pacific 
Linguistics Series D - No. 38). Canberra: The Australian National University.

Poedjosoedarmo, Soepomo. 1992. "Unsur Lama dalam Tatabahasa Dialek Melayu Brunei." SUMBANGSIH UBD, Brunei: Akademi Pangajian Brunei, Universiti Brunei Darussalam

Schwabe, Kerstin dan Wrinkler, Susanne. 2007. On Information Structure, Meaning, and Form. Amsterdam: John Benjamin Publishing.

Shopen, Timothy (Ed). 2007. Language Typology and Syntactic Description Volume I: Clause Structure. Cambridge: Cambridge University Press.

Soeparno. 2008. Aliran Tagmemik: Teori, Analisis, dan Penerapan dalam Pembelajaran Bahasa. Yogyakarta: Tiara Wacana.

Sutopo, H.B. 2006. Metode Penelitian Kualitatif. Surakarta: Sebelas Maret University Press.

Tallerman, Maggie. 2004. Understanding Syntax. London: Hodder Education.

Wijana, I Dewa Putu. 2010. Pengantar Semantik Bahasa Indonesia. Yogyakarta: Pustaka Pelajar.

Zimmerman, Malte dan Féry, Caroline. 2010. Information Structure: Theoretical, Typological, and Experimental Perspectives. Oxford: Oxford University Press.

\section{Sumber Data}

Butar-Butar, Maruli. 1978. "Suatu Pengamatan tentang Kalimat Cleft (Cleft Sentence) dalam Bahasa Indonesia." Dalam Majalah Bahasa dan Sastra, $\mathrm{VI}(3): 11-17$.

Cann, Ronnie. 2007. "Towards a Dynamic Account of Be in English", dalam Comorovski, Ileana, dan von Heusinger, Klaus. 2007. Existence: Semantics and Syntax. Dordrecht: Springer.

Caro, Elena Martinez. 1993. "Non-SVO Constructions in English: Some Pragmatic and Functional Considerations," dalam Revista Alicantina de Estudios Ingleses, 6(1):115-130.

Casielles-Suarez, Eugenia. 2004. The Syntax-Information Structure Interface. London: Routledge.

Creswell, Casandre. 2004. Syntactic Form and Discourse Function in Natural Language Generation. New York: Routledge.

Crystal, David. 2008. A Dictionary of Linguistics and Phonetics. Oxford: Blackwell.

Dahl, Roald. 2007. The Twits. London: Puffin Books.

Downing, Angela. 2006. English Grammar: A University Course. London: Routledge.

Dryer, Matthew S. 2005. "Three Types of NP Preposing in English", University of NY at Buffalo (www.linguistics.buffalo.edu), diakses pada 3 Mei 2014, pukul 22:00 WIB.

Farrell, Patrick. 2005. Grammatical Relations. Oxford: Oxford University Press.

Hornby, A.S. 2005. Oxford Advanced Learner's Dictionary. Oxford: Oxford University Press.

Lapoliwa, Hans. 1990.Klausa Pemerlengkapan dalam Bahasa Indonesia. Yogyakarta: Penerbit Kanisius.

Levin, Beth dan Hovav, Malka Rapaport. 2005. Argument Realization. Cambridge: Cambridge University Press.

Levin, Beth. 1993. English Verb Classes and Alternations. Chicago: The University 
of Chicago.

Moro, Andrea. 1997. The Raising of Predicate. Cambridge: Cambridge University

Prince, Ellen F. 1981. "Topicalization, Focus Movement, and Yiddish-Movement", dalam: Dan Alford dkk (eds.). Proceedings of the Seventh Annual Meeting of the Berkeley Linguistics Society, 249-264.

Quirk, Randolph, Alfred Charles Gimson, dan Jeremy Warburg. 1972. The Use of English. London: Longman Group.

\section{Daftar Laman Sumber Data}

www.writingcenter.unc.edu

www.mcp.anu.edu.au

www.grammar.about.com

www.usingenglish.com 